\title{
THE IMPACT OF FOREIGN DIRECT INVESTMENT ON THE ECONOMIC GROWTH IN MONGOLIA
}

\author{
Baasandulam Mavidkhaan \\ Ph.D. Candidate, \\ School of Business, Hunan University of Science and Technology, \\ Xiangtan city, Hunan province, Republic of China
}

\begin{abstract}
Mongolian foreign direct investment is governed by the "Constitution", "Foreign Investment Law" and other laws as well as international treaties to which Mongolia is a party. Mongolian s foreign direct investment fell by $35.8 \%$ from 2010 to $2011,43.52 \%$ from 2012 to 2013, and 27.3\% from 2014 to 2018. In recent years, there has been a trend of focusing foreign direct investment in the mining industry. As the inflow of foreign direct investment declines and the outflow increases, the economy still faces a series of problems, including foreign debt, budget deficits, exchange rates, and unemployment. This highlights the need to pay attention to the current investment environment and investment attractiveness policies, as well as appropriate policies that are in Mongolia's interests. For this reason, it is still necessary to determine the prospects of foreign direct investment in Mongolia, the concentration of foreign direct investment in the non-mining sector, the implementation of foreign direct investment policy and its impact on the economy. Therefore, the purpose is to study and improve Mongolia's foreign direct investment policy.
\end{abstract}

Keywords: Foreign Direct Investment, Mongolia, Influence, Gross Domestic Product, Mining Industry

\section{Mongolian economy and foreign direct investment situation}

Mongolian "National Security Concept" defines the role and importance of foreign direct investment in the economy from three aspects. First, foreign direct investment should account for at least one-third of total foreign investment, and should balance investment in strategically important ministries in neighboring countries and other developed countries. Second, foreign direct investment will be used to increase the accumulation of domestic capital, and the competitiveness of domestic enterprises will be improved by improving management skills and technology. Third, improving the competitiveness of domestic enterprises will create domestic enterprises to invest and trade overseas and ensure economic development. Foreign investment is very important if it can implement sound foreign investment policies that will not adversely affect Mongolian national security.

The transition to a free economy in 1990 and the passage of the 1993 "Foreign Direct Investment Law" increased Mongolia's total trade and accelerated investment flows. Although the mining industry has been active since the early 2000 s, and the catering, retail and wholesale production sectors have been restored, foreign direct investment in wholesale and retail trade and agricultural Industry were declined. Due to the small economic scale of Mongolia, the investment in the mining industry alone has increased the total domestic production. In the 2000s, Mongolian economic structure changed, the Agricultural industry took the lead, and the role of the mining industry increased. In 2011, Mongolian economy grew rapidly. The main reason was the sharp increase in foreign direct investment in the mining industry. As of 2018, the mining industry accounted for $24.6 \%$ of Mongolian economy, wholesale and retail trade accounted for $16.3 \%$ of Mongolian economy, and agriculture accounted for 10.7\%, and manufacturing accounted for $10.9 \%$ of Mongolian economy.

Table1.

Mongolian Economic Structure

\begin{tabular}{|c|c|c|c|c|}
\hline Population & 2018 & & & \\
\hline Total (Millions) & 3238 & & & \\
\hline Ulaanbaatar(Millions) & 2197 & & & \\
\hline Urban population (Share of total population) & $67.8 \%$ & & & \\
\hline Gross Domestic Product & 2008 & 2011 & 2014 & 2018 \\
\hline At the price of the year, ten thousand dollars & 488.2 & 829.2 & 571.9 & 570.2 \\
\hline GDP per capita, at current year's price & 2.12 & 3.73 & 4.07 & 3.98 \\
\hline Total Trade & 2008 & 2011 & 2014 & 2018 \\
\hline One hundred million U.S. dollars & 5.8 & 11.4 & 10.6 & 12.8 \\
\hline Exports (Share of total domestic production) & $39 \%$ & $37 \%$ & $26 \%$ & $22.4 \%$ \\
\hline Imports (Share of total domestic production) & $49 \%$ & $50 \%$ & $24 \%$ & $18.9 \%$ \\
\hline Macroeconomic environment & 2008 & 2011 & 2014 & 2018 \\
\hline Government debt & $40 \%$ & $43 \%$ & $57 \%$ & $26.6 \%$ \\
\hline Inflation rate & $28 \%$ & $9.2 \%$ & $18.8 \%$ & $8.1 \%$ \\
\hline Corruption Index & 3 & 2.7 & 3.9 & 3.7 \\
\hline Exchange rate (tugrik to U.S. dollar) & 1166 & 1266 & 1817 & 2472.4 \\
\hline
\end{tabular}




\begin{tabular}{|c|c|c|c|c|}
\hline Economic activity as a share of GDP & 2008 & 2011 & 2014 & 2018 \\
\hline (Share of GDP) & 2008 & 2011 & 2014 & 2018 \\
\hline Mining industry & 20.6 & 21.8 & 17.6 & 26.8 \\
\hline Wholesale and retail trade & 13.7 & 22.1 & 14.0 & 16.3 \\
\hline Processing Industry & 8.3 & 8.6 & 10.6 & 10.9 \\
\hline Transport and storage & 6.5 & 6.2 & 4.5 & 4.7 \\
\hline Real estate activity & 5.3 & 6.8 & 6.1 & 5.7 \\
\hline Construction,building & 2.5 & 3.7 & 5.8 & 4.3 \\
\hline Major mineral resources & \multicolumn{4}{|l}{ Copper, coal, gold, iron ore, phosphorus, zinc, uranium, silver } \\
\hline
\end{tabular}

Information Sources : www.1212.mn

At the same time, the slowdown in economic growth in China (our main trading partner) and the decline in world commodity prices are external factors that have led to the decline in export demand. Since 2012, foreign direct investment has declined, and macroeconomic indicators (such as the share of government debt in GDP, inflation, corruption index, and exchange rate) are expected to deteriorate. Although total trade has increased, the share of imports and exports of goods and services in GDP has fallen. Then, the Oyutolgoi project is the core of mining industry investment. Due to certain problems, the investment stopped its investment in 2013-2016 and resumed again in 2017.

Table 2.

The Relationship Between Foreign Ddirect Investment and Economic Growth Rate

\begin{tabular}{|c|c|c|c|c|}
\hline & 2008 & 2011 & 2014 & 2018 \\
\hline Total investment (100 million US dollars) & 21461.5 & 83878.7 & 60424.8 & 125515.1 \\
\hline Investment in the mining industry(\%) & 22.6 & 61.9 & 15.2 & 41.8 \\
\hline Investment growth rate(\%) & 11.6 & 17.5 & -8.9 & 21.4 \\
\hline Economic growth rate (\%) & 8.9 & 17.5 & 7.8 & 16.2 \\
\hline
\end{tabular}

Information Sources : www.1212.mn

Economic growth directly depends on foreign direct investment. However, most foreign direct investment is only in the mining industry, including only the OyuTolgoi project. Therefore, Mongolian economy depends on a single ministry and is fragile. Before the agreement was

signed in 2009 and suspended in 2013, Oyutolgoi's investment grew rapidly, reaching more than US\$7 billion, accounting for 54\% of the total investment in 2010-2013 and $85 \%$ of the mining industry investment. This confirms that Mongolia is dependent on the mining industry and its economic structure is unitary. In addition, China has been the main contributor of Mongolia's foreign direct investment, which has remained until 2009. Since 2010, it has been dominated by investments from the Netherlands and Canada.

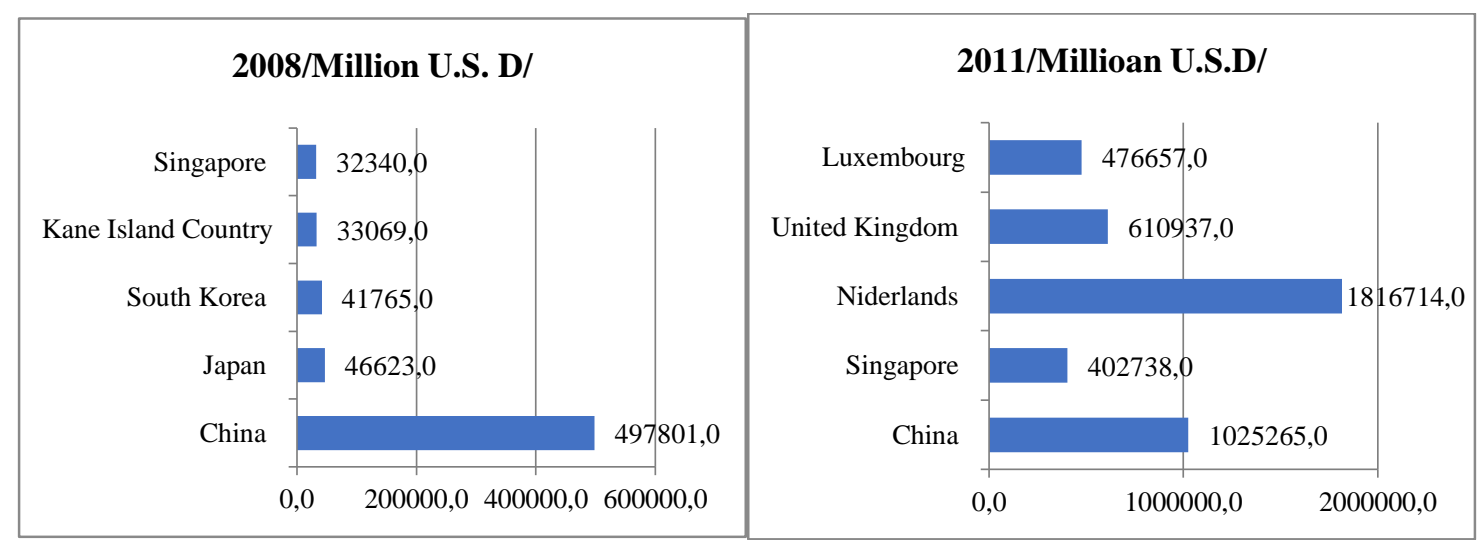




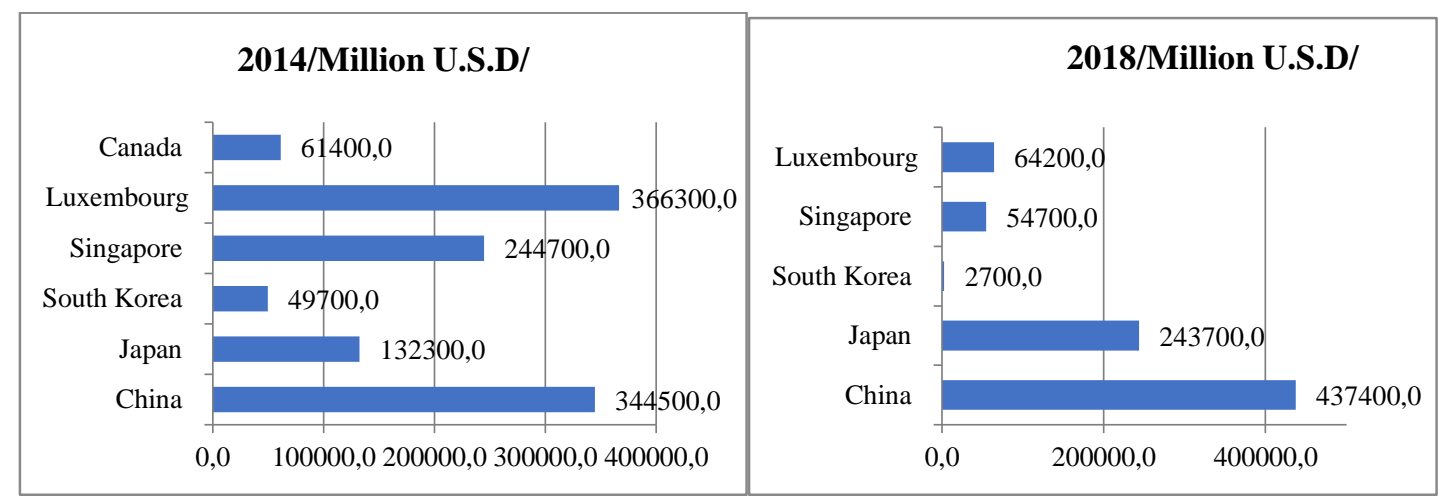

Figure1. Mongolian Main Investment Partners

Information Sources : $\underline{w w w .1212 . m n}$

As of 2018, there are approximately 14,000 foreign-invested companies in Mongolia, of which $48.3 \%$ are Chineseinvested companies, mainly in the fields of light industry, catering, hotels, construction, animal husbandry, agriculture and mining. At the same time, the table below shows that of the 20 largest companies with foreign participation, 7 are operating in the mining industry and 4 are in the banking industry.

20 largest companies with foreign participation

\begin{tabular}{|c|c|c|c|c|c|c|}
\hline № & Company Name & $\begin{array}{l}\text { Time of } \\
\text { entry }\end{array}$ & $\begin{array}{l}\text { Net worth } \\
\text { (USD100 } \\
\text { million) }\end{array}$ & $\begin{array}{l}\text { Foreign } \\
\text { investment } \\
\text { share }\end{array}$ & Areas of activity & Stakeholders \\
\hline 1 & Oyutolgoi & 2000 & 108.05 & $66 \%$ & Mining & $\begin{array}{l}\text { Netherlands, British Virgin } \\
\text { Islands, Mongolia }\end{array}$ \\
\hline 2 & $\begin{array}{c}\text { Peabody Winsway } \\
\text { Resources }\end{array}$ & 2007 & 61.0 & $100 \%$ & Mining & Netherlands \\
\hline 3 & Chinggis Khaan Bank & 2006 & 32.6 & $100 \%$ & Banking & British Virgin Islands \\
\hline 4 & Tethys Mining & 2004 & 26.9 & $100 \%$ & Mining & Switzerland \\
\hline 5 & Boldtomor Yoroo Gol & 2004 & 18.9 & $100 \%$ & Mining & British Virgin Islands \\
\hline 6 & Goyo & 2006 & 18.0 & $100 \%$ & Cashmere & Singapore \\
\hline 7 & Khan Bank & 2004 & 20.6 & $66 \%$ & Banking & $\begin{array}{l}\text { Japan, Mongolia, China, } \\
\text { Hong Kong, United States }\end{array}$ \\
\hline 8 & MCS Asia Pacific & 2005 & 23 & $55 \%$ & Water, drinks & Singapore, Mongolia \\
\hline 9 & Areva Mongolia & 2005 & 12.5 & $100 \%$ & Mining & France \\
\hline 10 & Mobicom Corporation & 1995 & 10.7 & $79 \%$ & Communication & Netherlands, Mongolia \\
\hline 11 & Ulaanbaatar University & 1995 & 6.7 & $98 \%$ & Education & $\begin{array}{c}\text { South Korea, United States, } \\
\text { Mongolia }\end{array}$ \\
\hline 12 & $\begin{array}{l}\text { Wagner Asia } \\
\text { Equipment }\end{array}$ & 1996 & 6.4 & $100 \%$ & $\begin{array}{l}\text { Machinery, } \\
\text { equipment }\end{array}$ & United States \\
\hline 13 & Sky Resort & 2008 & 20.9 & $26 \%$ & Tourism & $\begin{array}{c}\text { Mongolia, United } \\
\text { Kingdom }\end{array}$ \\
\hline 14 & Central Asian Cement & 2003 & 5.5 & $98 \%$ & $\begin{array}{l}\text { Construction, } \\
\text { Building }\end{array}$ & $\begin{array}{c}\text { China, HongKong,United } \\
\text { States, Mongolia, } \\
\text { Singapore } \\
\end{array}$ \\
\hline 15 & $\begin{array}{c}\text { Trade Development } \\
\text { Bank }\end{array}$ & 2002 & 3.8 & 80 & Banking & $\begin{array}{c}\text { Luxembourg, Mongolia, } \\
\text { United States }\end{array}$ \\
\hline 16 & Mongolrostvestment & 2007 & 10.5 & $49 \%$ & Mining & Mongolia, Russia \\
\hline 17 & $\begin{array}{l}\text { Qing Hua-MAC- } \\
\text { Nariin Sukhait }\end{array}$ & 2002 & 3.6 & $50 \%$ & Mining & China, Mongolia \\
\hline 18 & $\begin{array}{c}\text { National Investment } \\
\text { Bank }\end{array}$ & 2006 & 3.2 & $44 \%$ & Banking & Mongolia, Cayman Islands \\
\hline 19 & Sunjin Group & 2006 & 2.3 & $100 \%$ & Tourism & South Korea \\
\hline 20 & Seoul Group & 1996 & 1.1 & $95 \%$ & Real state & South korea, Mongolia \\
\hline & Total & & 470.5 & $79 \%$ & & \\
\hline
\end{tabular}

Information Sources: D.Munkgtsetseg."Foreign Direct Investment Appropriate Policy”2015:662 
Mongolia was joined the "Vienna Convention on the Law of Treaties" in 1988 and has ratified and approved the implementation of any international treaties. A total of 111 countries have joined the agreement, and Mongolia has joined multilateral agreements and conventions related to foreign investment laws and regulations. 
List of Multilateral Agreements Related to the Legal Regulation of Foreign Investment

Table4. to which Mongolia is a party

\begin{tabular}{|c|c|c|c|}
\hline Name of the contract & $\begin{array}{l}\text { Established } \\
\text { date }\end{array}$ & $\begin{array}{l}\text { Effective } \\
\text { date }\end{array}$ & $\begin{array}{l}\text { Date of accession of } \\
\text { Mongolia }\end{array}$ \\
\hline $\begin{array}{l}\text { Convention on the limitation period for the sale of international } \\
\text { goods }\end{array}$ & 1974.06 .12 & 1988.08.01 & 1974 \\
\hline $\begin{array}{c}\text { Washington Convention on the Settlement of Investment Disputes } \\
\text { between States and Foreign Citizens }\end{array}$ & 1965.03 .18 & 1966.10.14 & 1996.05.28 \\
\hline Marrakesh Agreement Establishing the World Trade Organization & 1994.04 .15 & 1995.01 .01 & 1996.12.26 \\
\hline $\begin{array}{l}\text { International sale and purchase of goods } \\
\text { Vienna Convention on Treaties }\end{array}$ & 1980.04.11 & 1988.01.01 & 1997.07.09 \\
\hline $\begin{array}{l}\text { Convention on the Establishment of a Multilateral Investment } \\
\text { Guarantee Agency }\end{array}$ & 1985.10 .11 & 1988.04.12 & 1998.07.23 \\
\hline
\end{tabular}

Information Sources: D.Munkgtsetseg.“Foreign Direct Investment Appropriate Policy”2015:663

\section{Analysis of the impact of foreign direct investment on Mongolia's economy}

2.1 Data source

A sample period of 29 years has been selected for the study for the period 1990-2018 with annual time series. Different sources were used to collect the data. The FDI, GDP, Employment, Domestic Capital Investment and Export were obtained from Bank of Mongolia and Statistical Office of Mongolia. The consumer Price index was obtained from world bank data. For the human capital, there are various indicators of human capital stock. Due to the diverse use of human capital in different fields of research, the lack of data and theoretical debates, there is no clear consensus of what should be the proxy for human capital. In this study, the enroll in total university was used as a proxy for human capital. This statistics was obtained from relevant literature.

2.2 Theoretical hypothesis

This research proposes the following hypotheses.

$>$ This study expects that FDI and domestic capital investment have a positive effect on economic growth. As a result, the domestic market will develop and domestic production will increase.

$>$ The expansion and diversification of a country's trade and potential markets creates more economic competitiveness. Since economic diversification can be achieved through export trade, the interaction between export trade and foreign direct investment will have a positive impact on economic growth.

$>$ Economic growth will be accompanied by an increase in labor-intensive production, and labor will be able to benefit from economic growth.

$>$ With the acceleration of economic growth, the growth of skilled technicians will have a big impact on economic growth, because technology will be updated and skilled personnel will be required. High quality labour force should produce more from a given resources.

$>$ As the economy grows, the consumer price index will stabilize and the exchange rate will stop rising.

2.3 Model Specification

To test the relationship between economic growth (GDP) and FDI, Domestic Capital Invest , Employment, Consumer Price Index, Export, human Capital variables, we estimated a linear regression model of the following form by using the SPSS with Ordinary Least Squares (OLS) estimator.

$$
\mathrm{GDP}=\mathrm{C}+\beta_{1} \mathrm{FDI}+\beta_{2} \mathrm{DCM}+\beta_{3} \mathrm{EMP}+\beta_{4} \mathrm{CPI}+\beta_{5} \mathrm{EXP}+\beta_{6} \mathrm{HC}+\mathrm{e}
$$

Where:

Real GDP, Expressed GDP, Unit is million U.S.D

Foreign Direct Invest, Expressed FDI, Unit is million U.S.D

Domestic Capital Invest, Expressed DCI, Unit is million U.S.D

Employment, Expressed EMP, Unit is person

Consumer price index, Expressed CPI, Unit is \%

Export Rate, Expressed EXP, Unit is million of U.S. D

Human Capital, Expressed HC, Unit is student 


\begin{tabular}{|c|c|c|c|c|c|c|c|c|}
\hline \multicolumn{9}{|c|}{ Correlations } \\
\hline & & GDP & DCI & FDI & EMP & CPI & EXP & $\mathrm{HC}$ \\
\hline & Pearson Correlation & 1 & $.932^{* * *}$ & $.848^{* *}$ & $.771^{* * *}$ & $.776^{* *}$ & $.626^{* *}$ & $.609^{* *}$ \\
\hline \multirow{3}{*}{ GDP } & Sig. (2-tailed) & & .000 & .000 & .000 & .000 & .000 & .000 \\
\hline & $\mathrm{N}$ & 29 & 29 & 29 & 29 & 29 & 29 & 29 \\
\hline & Pearson Correlation & $.932^{* *}$ & 1 & $.883^{* *}$ & $.769^{* * *}$ & $.798^{* *}$ & $.643^{* *}$ & $.590^{* *}$ \\
\hline \multirow[t]{3}{*}{ DCI } & Sig. (2-tailed) & .000 & & .000 & .000 & .000 & .000 & .001 \\
\hline & $\mathrm{N}$ & 29 & 29 & 29 & 29 & 29 & 29 & 29 \\
\hline & Pearson Correlation & $.848^{* *}$ & $.883^{* * *}$ & 1 & $.840^{* * *}$ & $.831^{* *}$ & $.735^{* *}$ & $.745^{* *}$ \\
\hline \multirow[t]{2}{*}{ FDI } & Sig. (2-tailed) & .000 & .000 & & .000 & .000 & .000 & .000 \\
\hline & $\mathrm{N}$ & 29 & 29 & 29 & 29 & 29 & 29 & 29 \\
\hline & Pearson Correlation & $.771^{* * 4}$ & $.769^{* *}$ & $.840^{* * *}$ & 1 & $.965^{* *}$ & $.775^{* *}$ & $.847^{* *}$ \\
\hline \multirow[t]{2}{*}{ EMP } & Sig. (2-tailed) & .000 & .000 & .000 & & .000 & .000 & .000 \\
\hline & $\mathrm{N}$ & 29 & 29 & 29 & 29 & 29 & 29 & 29 \\
\hline & Pearson Correlation & $.776^{* *}$ & $.798^{* * *}$ & $.831^{* *}$ & $.965^{* *}$ & 1 & $.772^{* * *}$ & $.779^{* *}$ \\
\hline \multirow[t]{2}{*}{ CPI } & Sig. (2-tailed) & .000 & .000 & .000 & .000 & & .000 & .000 \\
\hline & $\mathrm{N}$ & 29 & 29 & 29 & 29 & 29 & 29 & 29 \\
\hline & Pearson Correlation & $.626^{* *}$ & $.643^{* * *}$ & $.735^{* *}$ & $.775^{* *}$ & $.772^{* *}$ & 1 & $.765^{* *}$ \\
\hline \multirow[t]{2}{*}{ EXP } & Sig. (2-tailed) & .000 & .000 & .000 & .000 & .000 & & .000 \\
\hline & $\mathrm{N}$ & 29 & 29 & 29 & 29 & 29 & 29 & 29 \\
\hline \multirow{3}{*}{$\mathrm{HC}$} & Pearson Correlation & $.609^{* *}$ & $.590^{* *}$ & $.745^{* *}$ & $.847^{* *}$ & $.779^{* *}$ & $.765^{* *}$ & 1 \\
\hline & Sig. (2-tailed) & .000 & .001 & .000 & .000 & .000 & .000 & \\
\hline & $\mathrm{N}$ & 29 & 29 & 29 & 29 & 29 & 29 & 29 \\
\hline
\end{tabular}

The correlation matrix on Table 5 above shows that FDI is positively stronger related to Gross Domestic Product.

2.4 Multiple Regression Analysis

The study conducted multiple regression analysis to determine the relationship between foreign direct investment and economic growth in Mongolia. The findings of the study are presented in the tables below.

Model Summary ${ }^{b}$

\begin{tabular}{|c|c|c|c|c|c|}
\hline Model & $\mathrm{R}$ & $\mathrm{R}$ Square & Adjusted R Square & Std. Error of the Estimate & Durbin-Watson \\
\hline 1 & $.938^{\mathrm{a}}$ & .880 & .847 & .206690264553289 & 2.617 \\
\hline
\end{tabular}

edictors: (Constant), Human Capital , Domestic Capital Invest, Export, Consumer Price Index, Foreign Direct Invest, Employment

b. Dependent Variable: GDP

The six independent variables include Domestic Capital Invest, Foreign Direct Invest, Employment, Consumer Price Index, Export and Human Capital that were studied, indicate 88\% of the variance in economic growth in Mongolia as represented by $\mathrm{R}^{2}$. It means that other factors not included in this study contribute $12 \%$ of the variance in the dependent variable.

Table7.

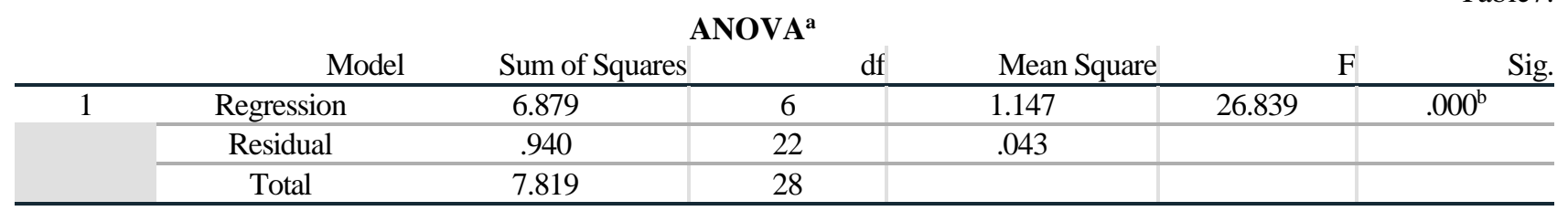

a. Dependent Variable: GDP

b. Predictors: (Constant), Human Capital , Domestic Capital Invest, Export, CPI, FDI, Employment

The findings show that the significance value is less than $5 \%$, so the model is statistically considerable to predict how Domestic Capital Invest, Foreign Direct Invest, Employment, Consumer Price Index, Export and Human Capital affect the Gross Domestic Product of Mongolia.

Table8.

Regression Analysis 


\begin{tabular}{|c|c|c|c|c|c|c|c|c|}
\hline \multirow{2}{*}{\multicolumn{2}{|c|}{ Model }} & \multicolumn{2}{|c|}{$\begin{array}{l}\text { Unstandardized } \\
\text { Coefficients }\end{array}$} & \multirow{2}{*}{$\begin{array}{c}\text { Standardized } \\
\text { Coefficients } \\
\text { Beta }\end{array}$} & \multirow{2}{*}{$\mathrm{t}$} & \multirow{2}{*}{ Sig. } & \multirow[t]{9}{*}{ Correlations } & \multirow[t]{9}{*}{$\begin{array}{c}\text { Collinearity } \\
\text { Statistics }\end{array}$} \\
\hline & & B & $\begin{array}{c}\text { Std. } \\
\text { Error }\end{array}$ & & & & & \\
\hline & (Constant) & -12.516 & 13.410 & & -.933 & .361 & & \\
\hline & DCI & .896 & .182 & .863 & 4.914 & .000 & & \\
\hline & FDI & 3.004 & .174 & .004 & .021 & .002 & & \\
\hline \multirow[t]{4}{*}{1} & Emp & 2.399 & 2.400 & .352 & 1.000 & .328 & & \\
\hline & CPI & -.002 & .003 & -.244 & -.770 & .450 & & \\
\hline & Exp & -.008 & .048 & -.020 & -.156 & .878 & & \\
\hline & $\mathrm{HC}$ & .008 & .323 & .004 & .024 & .981 & & \\
\hline
\end{tabular}

The $\mathrm{F}$ calculated value is greater than the $\mathrm{F}$ critical value which shows that the overall model was significant. From the regression findings in Table 9 below, the results revealed that a unit increase in Domestic Capital Invest will lead to 0.896 rises in GDP; a unit increase in the FDI would lead to 3.004 rises in GDP; a unit increase in the Employment will result in 2.399 rises in GDP; whereas a unit increase in Consumer Price Index increase will lead to 0.002 decrease in GDP; a unit increase in the export will lead to decrease 0.008 in GDP; a unit increase in Human Capital would led to 0.008 rises in GDP. At 5\% level of significance and 95\% level of confidence, FDI had a 0.000 level of significance; Employment, Consumer Price Index, Export and Human Capital Index showed insignificance to GDP.

\section{Conclusion}

The results of the study are very interesting and in line with the results obtained by other researchers on the relationship between economic growth and the FDI. The study intends to investigate the Impact of foreign direct investment on economic growth in Mongolia. The study has used data 1990-2018 by using Two-Stage least squares method of simultaneous equations the results have been estimated. The empirical results show that there is positive relationship between the economic growth and FDI in the belief to charge of growth and development. This relationship could be as a result of sufficient FDI fund invested into Mongolia's economy which has been able to enough impact to make it positive or growth enhancing. FDI is believed to transfer technology, promote learning by doing, train labor and in general, results in spillovers of human skills and technology. Mongolian export and consumer price index are indicate that the transfer of high technology and knowledge has an adverse impact on Mongolian economic growth.

On the other hand, according to the National Security Concept of our country, the investment of one country should not exceed $1 / 3$ of the total foreign investment. Restrictions on the ownership of a state-owned company are regulations that limit the dependence on a single state. However, this provision has not been implemented in practice. Prior to 2009, more than $60 \%$ of total foreign investment came from China alone, while in $201138 \%$ of total foreign investment and in $201440 \%$ of total foreign investment came from Luxembourg alone. Mongolia needs to take into account the impact of international agreements when working with foreign investors. International experience shows that we can do the following to reduce over-reliance on mining. In the first stage, it is necessary to look for opportunities to accumulate and use the mining revenues more efficiently without spending them completely. Second, it is necessary to use the savings in a policy to support other sectors and, most importantly, to allow only domestic producers.

\section{References}

1. "The Impact of Foreign Direct Investment on Economic Growth: A Case Study of South Korea", Casetsart University of Thailand.

2. "Mongolia Investment Climate Statement -2017".

3. The World bank. "Mongolian Investment Environmental Reform Map"2018

4. "Mongolia: Comprehensive Analysis".

5. L.Udval."20 Years of Mongolia's Foreign Policy Concept" Ministry of Foreign Affairs of Mongolia. 2014

6. "Study on the Legal Regulation of Foreign Direct Investment in Mongolia". National Institute of Law.

7. D.Davaasukh, N.Amar. "Impact of the Chinese Economy on Mongolia" Bank of Mongolia, 2012

8. N.Anand. "The Impact of Foreign Direct Investment in Real Economic Sectors". Bank of Mongolia, 2018

9. "Mongolia's Foreign Trade Policy Issues to Consider". Bank of Mongolia, 2018

10. KPMG. "Investment in Mongolia".2016

11. The world bank "Economic Review of Mongolia".2014

12. The world bank "Investment Reform Map for Mongolia"2018

13. B.Nandin-Erdene."Political and Economic Analysis of Foreign Direct Investment in Mongolia", Science and Technology Foundation, 2017

14. Ch.Naranchimeg. "Analysis of Factors affecting the Economy", Science and Technology Foundation, 2015 
15. S.Nergui, "Study on the Impact of Foreign Direct Investment on Economic Growth" Science and Technology Foundation, 2018 